\title{
Fatty acid composition of milk from Holstein x Gyr cows grazing on marandu grass supplemented with concentrate containing sunflower oil
}

\section{Perfil de ácidos graxos do leite de vacas Holandês x Gir pastejando capim-marandu suplementado com concentrado contendo óleo de girassol}

\author{
Bárbara Cardoso da Mata e Silva ${ }^{1}$; Norberto Mario Rodriguez ${ }^{2}$; \\ Mirton José Frota Morenz ${ }^{3}$; Carlos Augusto de Miranda Gomide; \\ Carlos Eugênio Martins ${ }^{3}$; Domingos Sávio Campos Paciullo; \\ Marco Antônio Sundfeld da Gama ${ }^{3}$; Fernando César Ferraz Lopes ${ }^{4 *}$
}

\begin{abstract}
The inclusion of plant oils in the diets of grazing cows represents a promising nutritional strategy for the production of milk naturally enriched with bioactive compounds, such as rumenic (cis-9, trans-11 CLA), vaccenic (trans-11 C18:1) and oleic (cis-9 C18:1) acids. The aim of this study was to evaluate the effect of dietary supplementation with sunflower oil (SO) on the fatty acid (FA) composition of milk from Holstein x Gyr dairy cows grazing on Urochloa brizantha cv. Marandu under rotational stocking. Sixteen multiparous cows with $185 \pm 10$ days in milk received a concentrate containing $0 \%$ (control) or $15 \% \mathrm{SO}$ on a dry matter basis in a randomized block design with two replications (paddocks). The results were analyzed with mixed models $(\mathrm{P} \leq 0.05)$ using repeated measurements over time, as represented by sampling days 14,35 and 62 (periods 1,2 and 3, respectively). In any period, an effect of SO supplementation was observed on milk production, pasture dry matter intake and nutrients intake, whereas the concentrations of most milk FA were altered in SO-fed cows. In particular, dietary supplementation with SO resulted in the production of milk enriched with FA beneficial to human health (rumenic, vaccenic and oleic acids) and with lower levels of hypercholesterolemic lauric (C12:0), myristic (C14:0) and palmitic (C16:0) acids. This positive effect on the nutritional quality of milk fat was more noticeable from the $40^{\text {th }}$ to $43^{\text {rd }}$ days of sunflower oil supplementation.
\end{abstract}

Key words: Brachiaria brizantha. Conjugated linoleic acid. Rumenic acid. Urochloa brizantha. Vaccenic acid.

1 Prof ${ }^{\mathrm{a}}$ Colaboradora, Universidade José do Rosário Vellano, UNIFENAS, Programa de Pós-Graduação em Reprodução, Sanidade e Bem-Estar Animal, Alfenas, MG, Brasil. E-mail: barbaracmsilva@yahoo.com.br

2 Prof. Emérito, Departamento de Zootecnia, Escola de Veterinária, Universidade Federal de Minas Gerais, UFMG, Belo Horizonte, MG, Brasil. E-mail: norberto.bhe@terra.com.br

3 Pesquisadores, Empresa Brasileira de Pesquisa Agropecuária, EMBRAPA Gado de Leite, Juiz de Fora, MG, Brasil. E-mail: mirton.morenz@embrapa.br; carlos.gomide@embrapa.br; carlos.eugenio@embrapa.br; domingos.paciullo@embrapa.br; marco.gama@embrapa.br

4 Analista, EMBRAPA Gado de Leite, Juiz de Fora, MG, Brasil. E-mail: fernando.lopes@embrapa.br

* Author for correspondence 


\section{Resumo}

A inclusão de óleos vegetais na dieta de vacas a pasto é uma estratégia nutricional promissora para a produção de leite naturalmente enriquecido com ácidos graxos bioativos como o rumênico (CLA cis-9, trans-11), vacênico (C18:1 trans-11) e oleico (C18:1 cis-9). Objetivou-se avaliar o efeito da suplementação da dieta com óleo de girassol sobre a composição de ácidos graxos do leite de vacas Holandês x Gir sob pastejo rotacionado em Urochloa brizantha cv. Marandu. Foram utilizadas 16 vacas multíparas com $185 \pm 10$ dias em lactação recebendo concentrado com $0 \%$ (controle) ou com $15 \%$ de inclusão de óleo de girassol com base na matéria seca, em delineamento de blocos ao acaso, com duas repetições de área de pastagem. Os resultados foram analisados utilizando-se modelos mistos $(\mathrm{P} \leq 0,05)$, com medidas repetidas no tempo, representadas pelos dias de amostragem 14, 35 e 62 (respectivamente, períodos 1, 2 e 3). A produção de leite e o consumo de matéria seca de pasto e de nutrientes não foram afetados pela suplementação lipídica em nenhum dos períodos, mas houve efeito sobre os teores da maioria dos ácidos graxos do leite. A suplementação do pasto com óleo de girassol permitiu produzir leite com maiores teores de ácidos graxos benéficos à saúde humana (rumênico, vacênico e oleico) e com menores teores dos ácidos graxos hipercolesterolêmicos láurico (C12:0), mirístico (C14:0) e palmítico (C16:0). O efeito positivo na qualidade nutricional da gordura do leite foi mais pronunciado do $40^{\circ}$ ao $43^{\circ}$ dia de suplementação com óleo de girassol.

Palavras-chave: Ácido linoleico conjugado. Ácido rumênico. Ácido vacênico. Brachiaria brizantha. Urochloa brizantha.

\section{Introduction}

The term conjugated linoleic acid (CLA) refers to the 28 positional and geometric isomers of linoleic acid (cis-9, cis-12 C18:2). Among these isomers, special attention has been devoted to cis9, trans-11 CLA (rumenic acid), which has shown anticarcinogenic, antidiabetogenic (type 2 diabetes), antiatherogenic and immunomodulatory properties. The main source of rumenic acid in the human diet is ruminant milk fat (YANG et al., 2015). Therefore, the production of dairy products enriched with this fatty acid (FA) and other FA also beneficial to health, such as oleic (cis-9 C18:1) and $\alpha$-linolenic acids (cis-9, cis-12, cis-15 C18:3) have been the subject of research in Brazil (LOPES et al., 2015) and worldwide (KLIEM; SHINGFIELD, 2016).

Tropical grasses have high contents of $\alpha$-linolenic and linoleic polyunsaturated-FAs (LOPES et al., 2015), the main substrates for the vaccenic acid formation in the rumen (trans-11 C18:1), which is the precursor for synthesis of $64 \%$ to $97 \%$ of all rumenic acid secreted in bovine milk (SHINGFIELD et al., 2010). In addition, the increase in rumenic and vaccenic acids contents in milk fat can be boosted by supplementing dairy cow diets with vegetable oils, such as sunflower oil, that are rich in linoleic acid (RIBEIRO et al., 2014).

Hence, milk production under grazing systems with tropical grasses supplemented with vegetable oils is a promising model for the production of milk enriched with rumenic, vaccenic and oleic bioactive FAs and with lower contents of lauric (C12:0), myristic (C14:0) and palmitic (C16:0) saturated FAs (LOPES et al., 2015) that are considered hypercholesterolemic (FAO, 2010).

Few studies on this subject have been conducted under tropical conditions, and most were performed by supplementing with oilseeds; agro-industry biodiesel coproducts; or with calcium salts of soybean, palm or CLA oils (LOPES et al., 2015). The dynamic of FA hydrolysis of free vegetable oils in the rumen is reasonably dissimilar from those observed when oilseeds are fed to cow. Therefore, the supplementation with free vegetable oils promotes different responses in milk FA composition (DHIMAN et al., 2000). In only three studies under tropical conditions, the pasture was supplemented with free vegetable oils. In these studies, only 
Girón et al. (2016) reported an increase in rumenic, vaccenic and oleic acids in milk fat by supplementing with corn oil, which is rich in linoleic acid. On the other hand, Lima et al. (2011) and Castaño et al. (2014), using palm oil with low linoleic acid content but serving as a source of palmitic acid, observed an increase in hypercholesterolemic FA contents in the obtained milk.

Another aspect not studied in tropical conditions concerns the FA composition in milk on the days after the beginning of lipid supplementation to cows managed under grazing, when maximum or minimum contents of FAs in the milk reach a level of interest for human health, as well as the dynamics per se of their milk fat contents during lipid supplementation. These responses are time-dependent, associated with changes in the ruminal environment and with variations in the biohydrogenation (BH) of FA due to the adaptation of rumen microbiota to the dietary lipid intake.

The aim of this study was to evaluate the effect of supplementation with sunflower oil on the temporal dynamics and changes in fatty acid composition of milk from Holstein x Gyr dairy cows managed under rotational grazing on Urochloa brizantha cv. Marandu.

\section{Materials and Methods}

The study was performed at Embrapa Dairy Cattle (Coronel Pacheco, MG, Brazil) from December 2012 to February 2013, and the experimental procedures used were approved by the Ethics Commission on Animal Use of Embrapa Dairy Cattle (CEUA Protocol n. 12/2013). The treatments consisted of supplementation or not with sunflower oil (SO) as a lipid source in the diet of dairy cows grazing on $U$. brizantha cv. Marandu. A randomized blocks design was used, represented by two replications (paddocks), with two treatments (inclusion or not of SO) and four replicates (cows) per treatment per block. Sixteen multiparous Holstein x Gyr cows with $185 \pm 10$ days in milk and $14.7 \pm 2.4 \mathrm{~kg}$ day $^{-1}$ of milk were used under rotational stocking in 4 ha of $U$. brizantha $\mathrm{cv}$. Marandu pasture, totaling 44 paddocks of $\sim 900 \mathrm{~m}^{2}$. In each paddock of each block, two cows were allocated to each treatment, homogeneously distributed according to parity, genetic group, milk production and body weight, observed in the pre-experimental period.

An average of $2.86 \mathrm{~kg} \mathrm{cow}^{-1}$ day $^{-1}$ of dry matter (DM) of concentrate (Table 1) was supplied in individual troughs during daily milking (06h00 and $14 \mathrm{~h} 00$ ). The concentrate with SO was prepared weekly to minimize its lipid peroxidation. The levels of oleic, linoleic and $\alpha$-linolenic acids in SO were $18.5 \%, 66.5 \%$ and $0.6 \%$, respectively. Concentrates were formulated to meet the nutritional requirements established in NRC (2001) for cows weighing 500 $\mathrm{kg}$ and producing $16 \mathrm{~kg}$ day $^{-1}$ of milk with $4 \%$ fat.

The pasture was managed under rotational stocking, with 30-day rest period and a 3-day grazing period, with the aim of achieving a postgrazing height of $25 \mathrm{~cm}$ and adjusting the stocking by a putand-take technique. The pasture was fertilized with $200 \mathrm{~kg} \mathrm{ha}^{-1}$ yearr $^{-1}$ of $\mathrm{N}$ and $\mathrm{K}_{2} \mathrm{O}$, and with $50 \mathrm{ha}^{-1}$ year ${ }^{-1}$ of $\mathrm{P}_{2} \mathrm{O}_{5}$.

Seven milk samplings were taken. The first sampling was performed the day before the beginning of concentrate supply, and then, at 2, 8, $14,20,35$ and 62 days of trial. After the milk yields had been recorded, and the collected raw milk of each cow had been homogenized, representative samples (aliquots of $2 / 3$ and $1 / 3$, at the morning and afternoon milking, respectively) were collected in bottles containing bronopol preservative and analyzed at the Milk Quality Laboratory of Embrapa Dairy Cattle (Juiz de Fora, MG, Brazil) for fat, protein, lactose, total solids and milk urea nitrogen (MUN). Simultaneously, milk samples were collected and stored at $-10^{\circ} \mathrm{C}$ in bottles without preservative to determine the FA profile by gas chromatography, as described by Ribeiro et al. (2014). This analysis was performed at the 
Laboratory of Chromatography of Embrapa Dairy Cattle (Juiz de Fora, MG, Brazil), using a 7820A chromatograph (Agilent Technologies Inc., Santa Clara, CA, USA) equipped with a fused silica capillary column (CP-Sil 88, $100 \mathrm{~m}$ x $0.25 \mathrm{~mm}$ x $0.2 \mu \mathrm{m}$; Varian Inc., Mississauga, ON, USA) and a flame ionization detector.
To complement this study on the nutritional quality of milk fat, the indices of atherogenicity (IA) and thrombogenicity (IT) and relations between omega 6:omega 3 FAs ( $\omega-6 / \omega-3$ FA ratio) and the hypocholesterolemic:hypercholesterolemic FA ratio (h/H FA ratio) were calculated as described by Silva et al. (2017).

Table 1. Centesimal and chemical composition of concentrates with and without sunflower oil (SO) and chemical composition of the pasture in the three periods.

\begin{tabular}{|c|c|c|c|c|c|c|}
\hline \multicolumn{7}{|c|}{ Centesimal composition (\% dry matter) } \\
\hline Ingredients & \multicolumn{4}{|c|}{ Without SO } & \multicolumn{2}{|l|}{ With SO } \\
\hline Ground corn & \multicolumn{4}{|c|}{58.1} & \multicolumn{2}{|l|}{39.5} \\
\hline Soybean meal & \multicolumn{4}{|c|}{35.9} & \multicolumn{2}{|l|}{39.5} \\
\hline Sunflower oil & \multicolumn{4}{|c|}{0.0} & \multicolumn{2}{|l|}{14.9} \\
\hline $\operatorname{MVP}^{(1)}$ & \multicolumn{4}{|c|}{4.4} & \multicolumn{2}{|l|}{4.5} \\
\hline Salt & \multicolumn{4}{|c|}{1.6} & \multicolumn{2}{|l|}{1.7} \\
\hline \multicolumn{7}{|c|}{ Chemical composition $^{(2)}$} \\
\hline $\mathrm{DM}(\%)$ & \multicolumn{4}{|c|}{$94.5 \pm 0.77$} & \multicolumn{2}{|l|}{$95.7 \pm 0.26$} \\
\hline $\mathrm{CP}(\% \mathrm{DM})$ & \multicolumn{4}{|c|}{$22.8 \pm 1.50$} & \multicolumn{2}{|l|}{$23.8 \pm 0.58$} \\
\hline $\mathrm{EE}(\% \mathrm{DM})$ & \multicolumn{4}{|c|}{$2.6 \pm 0.20$} & \multicolumn{2}{|l|}{$14.8 \pm 0.87$} \\
\hline NDF (\% DM) & \multicolumn{4}{|c|}{$12.1 \pm 0.67$} & \multicolumn{2}{|l|}{$11.8 \pm 0.38$} \\
\hline IVDMD (\%) & \multicolumn{4}{|c|}{$88.4 \pm 1.10$} & \multicolumn{2}{|l|}{$78.8 \pm 3.09$} \\
\hline \multicolumn{7}{|c|}{ Fatty acids - FA (mg g $\left.{ }^{-1} \mathrm{DM}\right)$} \\
\hline Palmitic & \multicolumn{4}{|c|}{$3.18 \pm 0.27$} & \multicolumn{2}{|l|}{$4.34 \pm 0.40$} \\
\hline Stearic & \multicolumn{4}{|c|}{$0.37 \pm 0.02$} & \multicolumn{2}{|l|}{$0.86 \pm 0.04$} \\
\hline Oleic & \multicolumn{4}{|c|}{$3.44 \pm 0.42$} & $6.77 \pm 0.66$ & \\
\hline Linoleic & & $7.30 \pm 0.73$ & & & $18.34 \pm 1.66$ & \\
\hline$\alpha$-linolenic & & $0.33 \pm 0.03$ & & & $0.44 \pm 0.04$ & \\
\hline & & Chemical com & osition of the & isture & & \\
\hline Composition & & od 1 & Per & & Per & d 3 \\
\hline $\mathrm{CP}(\% \mathrm{DM})$ & 14. & \pm 1.5 & 15. & 1.6 & 17.6 & \pm 1.9 \\
\hline $\mathrm{EE}(\% \mathrm{DM})$ & & 0.2 & & & & 0.2 \\
\hline NDF (\% DM) & 60. & \pm 2.3 & 62. & 2.3 & 61. & $=1.8$ \\
\hline IVDMD (\%) & 65. & \pm 2.0 & 65. & 1.5 & 67. & $=1.0$ \\
\hline Fatty acid & $\mathrm{mg} \mathrm{g}^{-1} \mathrm{DM}$ & $\mathrm{g} 100 \mathrm{~g}^{-1} \mathrm{FA}$ & $\mathrm{mg} \mathrm{g}^{-1} \mathrm{DM}$ & g $100 \mathrm{~g}^{-1} \mathrm{FA}$ & $\mathrm{mg} \mathrm{g}^{-1} \mathrm{DM}$ & ${\mathrm{g} 100 \mathrm{~g}^{-1} \mathrm{FA}}$ \\
\hline Palmitic & $6.13 \pm 0.61$ & $30.2 \pm 1.4$ & $4.77 \pm 0.80$ & $28.7 \pm 0.6$ & $5.89 \pm 1.60$ & $41.7 \pm 6.2$ \\
\hline Stearic & $0.34 \pm 0.02$ & $1.7 \pm 0.1$ & $0.29 \pm 0.04$ & $1.8 \pm 0.1$ & $0.31 \pm 0.01$ & $2.3 \pm 0.3$ \\
\hline Oleic & $0.89 \pm 0.06$ & $4.4 \pm 0.3$ & $0.64 \pm 0.05$ & $3.9 \pm 0.5$ & $0.41 \pm 0.05$ & $3.0 \pm 0.5$ \\
\hline Linoleic & $4.62 \pm 0.29$ & $22.7 \pm 0.7$ & $3.80 \pm 0.70$ & $22.8 \pm 0.5$ & $1.52 \pm 0.08$ & $10.9 \pm 0.9$ \\
\hline$\alpha$-linolenic & $7.03 \pm 0.69$ & $34.5 \pm 1.2$ & $5.99 \pm 1.34$ & $35.7 \pm 1.8$ & $2.71 \pm 0.28$ & $19.6 \pm 3.0$ \\
\hline
\end{tabular}

${ }^{(1)}$ MVP - Mineral-vitamin premix; (2)DM - dry matter; CP - crude protein; EE - ether extract; NDF - neutral detergent fiber; IVDMD - in vitro dry matter digestibility. 
Three sampling periods were performed to evaluate the chemical composition of the pasture and to estimate the individual DM intake at the time of milk sampling on days 14, 35 and 62 . The pasture DM intake was estimated using LIPE $^{\circledR}$ marker and the in vitro DM digestibility (IVDMD) of pasture. The procedures for administering the marker, sampling, processing and analysis of LIPE ${ }^{\circledR}$ in feces, in addition to calculations involving estimates of pasture DM intake, were performed as described by Silva et al. (2017). Additionally, in fecal samples, the ether extract (EE) content was analyzed. In each fecal sampling period, on the day before the cows enter the paddocks, forage samples were taken by simulated grazing at $25 \mathrm{~cm}$ height, the chemical compositions being summarized in Table 1 .

On the last day of each period, blood samples were collected following the procedures for sampling and analysis of plasma glucose concentrations, plasma urea nitrogen (PUN) and nonesterified FA (NEFA), as described by Silva et al. (2017). The FA profile was analyzed in plasma samples on day 62 also according to Silva et al. (2017).

Analyses of variance were performed using the MIXED procedure of SAS version 9.0, and effects were considered significant when $\mathrm{P} \leq 0.05$. The variables related to intake, fecal EE content, plasma metabolites (glucose, NEFA and PUN), milk production, composition and FA milk profile were analyzed using three repeated measures over time, represented by the days of sampling (DAY = 14, 35 and 62), respectively, for periods 1, 2 and 3.
On the other hand, the variation in the milk yield and composition, and the FA milk composition from the beginning of the concentrate supplementation to the end of the trial (temporal trends) was analyzed using seven repeated measures over time (DAY $=$ $0,2,8,14,20,35$ and 62). The fixed effects were treatment (supplementation of lipid to pasture SLP), block, DAY (or period) and the interaction SLP*DAY. The random effects were the blocks and their interactions. When the SLP*DAY interaction was significant, the SLICE option of LSMEANS was used. In temporal trends, linear and quadratic regressions were performed as a function of DAY and of the means of the variables evaluated in MIXED. For analysis of plasma FA contents (DAY $=62$ ), the treatment and block were considered fixed effects and cow*block was considered a random effect. Pearson's correlation and regression studies were performed using the CORR and REG procedures of SAS, respectively.

\section{Results and Discussion}

No interaction (SLP*DAY) nor effect $(\mathrm{P}>0.05)$ of SO supplementation was observed for the variables related to $\mathrm{DM}$, crude protein $(\mathrm{CP})$ and neutral detergent fiber (NDF) intakes in any period (Table 2). The pasture and total DM intakes (Table 2) are within the ranges reported in the review by Lopes (2008) of 1.50-3.67\% BW and 1.77$3.70 \% \mathrm{BW}$, respectively, in cows grazing tropical forages supplemented with up to $6 \mathrm{~kg} \mathrm{cow}^{-1} \mathrm{day}^{-1}$ of concentrate. 
Table 2. Effect of period and supplementation with sunflower oil (SO) on pasture and nutrient intake in Holstein x Gyr cows grazing on marandu grass.

\begin{tabular}{|c|c|c|c|c|c|c|c|}
\hline \multirow{3}{*}{ Variable } & \multicolumn{3}{|c|}{ Without $\mathrm{SO}^{(1)}$} & \multicolumn{3}{|c|}{ With $\mathrm{SO}^{(1)}$} & \multirow{3}{*}{$\mathrm{SEM}^{(3)}$} \\
\hline & \multicolumn{3}{|c|}{ Period $^{(2)}$} & \multicolumn{3}{|c|}{ Period $^{(2)}$} & \\
\hline & 1 & 2 & 3 & 1 & 2 & 3 & \\
\hline \multicolumn{8}{|c|}{ Nutrient intake from pasture ${ }^{(4)}$} \\
\hline $\mathrm{DM}, \% \mathrm{BW}$ & $2.20 \mathrm{Ab}$ & $2.61 \mathrm{Aa}$ & $2.68 \mathrm{Aa}$ & $2.10 \mathrm{Ab}$ & $2.44 \mathrm{Aa}$ & $2.56 \mathrm{Aa}$ & 0.13 \\
\hline DM, kg day ${ }^{-1}$ & $11.3 \mathrm{Ab}$ & $13.0 \mathrm{Aa}$ & $13.5 \mathrm{Aa}$ & $11.2 \mathrm{Ab}$ & $12.7 \mathrm{Aa}$ & $13.6 \mathrm{Aa}$ & 0.55 \\
\hline NDF, kg day ${ }^{-1}$ & $6.85 \mathrm{Ab}$ & $8.18 \mathrm{Aa}$ & $8.33 \mathrm{Aa}$ & $6.79 \mathrm{Ab}$ & $7.93 \mathrm{Aa}$ & $8.38 \mathrm{Aa}$ & 0.34 \\
\hline $\mathrm{CP}, \mathrm{kg}$ day $^{-1}$ & $1.69 \mathrm{Ac}$ & $1.95 \mathrm{Ab}$ & $2.41 \mathrm{Aa}$ & $1.67 \mathrm{Ac}$ & $1.90 \mathrm{Ab}$ & $2.39 \mathrm{Aa}$ & 0.11 \\
\hline \multicolumn{8}{|c|}{ Total nutrient intake (pasture + concentrate) } \\
\hline $\mathrm{DM}, \% \mathrm{BW}$ & $2.75 \mathrm{Ab}$ & $3.19 \mathrm{Aa}$ & $3.24 \mathrm{Aa}$ & $2.63 \mathrm{Ab}$ & $3.00 \mathrm{Aa}$ & $3.11 \mathrm{Aa}$ & 0.14 \\
\hline DM, kg day ${ }^{-1}$ & $14.1 \mathrm{Ab}$ & $15.9 \mathrm{Aa}$ & $16.3 \mathrm{Aa}$ & $14.1 \mathrm{Ab}$ & $15.5 \mathrm{Aa}$ & $16.5 \mathrm{Aa}$ & 0.55 \\
\hline $\mathrm{CP}, \mathrm{kg}$ day $^{-1}$ & $2.38 \mathrm{Ab}$ & $2.59 \mathrm{Ab}$ & $3.02 \mathrm{Aa}$ & $2.34 \mathrm{Ac}$ & $2.60 \mathrm{Ab}$ & $3.06 \mathrm{Aa}$ & 0.11 \\
\hline EE, $\mathrm{g} \mathrm{day}^{-1 *}$ & $438 \mathrm{Bc}$ & $470 \mathrm{Bb}$ & $521 \mathrm{Ba}$ & $819 \mathrm{Aa}$ & $799 \mathrm{Aa}$ & $852 \mathrm{Aa}$ & 15.87 \\
\hline \multicolumn{8}{|c|}{ Total fatty acids intake (pasture + concentrate) } \\
\hline Stearic, $\mathrm{g}_{\text {day }}{ }^{-1}$ & $4.8 \mathrm{Bb}$ & $4.9 \mathrm{Bb}$ & $5.3 \mathrm{Ba}$ & $6.1 \mathrm{Ab}$ & $6.2 \mathrm{Ab}$ & $6.9 \mathrm{Aa}$ & 0.15 \\
\hline Oleic, g day ${ }^{-1 *}$ & $18.2 \mathrm{Bb}$ & $19.0 \mathrm{Ba}$ & $16.1 \mathrm{Bc}$ & $26.8 \mathrm{Ab}$ & $28.6 \mathrm{Aa}$ & $26.5 \mathrm{Ab}$ & 0.31 \\
\hline Linoleic, $\mathrm{g} \mathrm{day}^{-1}$ & $69.9 \mathrm{Ba}$ & $71.9 \mathrm{Ba}$ & $42.9 \mathrm{Bb}$ & $97.7 \mathrm{Aa}$ & $103.8 \mathrm{Aa}$ & $77.1 \mathrm{Ab}$ & 2.80 \\
\hline$\alpha$-linolenic, $\mathrm{g}_{\text {day }}{ }^{-1}$ & $80.4 \mathrm{Aa}$ & $79.7 \mathrm{Aa}$ & $38.7 \mathrm{Ab}$ & $80.1 \mathrm{Aa}$ & $77.7 \mathrm{Aa}$ & $38.3 \mathrm{Ab}$ & 4.34 \\
\hline
\end{tabular}

*Significant interaction between Lipid supplementation*Period $(\mathrm{P}<0.05)$.

${ }^{(1)}$ Within the same treatment (inclusion or not of SO), lowercase letters indicate no significant difference $(\mathrm{P}>0.05)$ among periods; ${ }^{(2)}$ Within the same period, uppercase letters indicate no significant difference $(\mathrm{P}>0.05)$ among treatments; ${ }^{(3)} \mathrm{SEM}-\mathrm{standard}$ error of the mean; ${ }^{(4)} \mathrm{DM}$ - dry matter; \%BW - \% of body weight; NDF - neutral detergent fiber; $\mathrm{CP}$ - crude protein; EE - ether extract.

The estimated EE contents in diet DM (pasture + concentrate) consumed by the cows in the treatments with and without SO supplementation were, on average, $3.24 \% \pm 0.13$ and $1.87 \% \pm$ 0.13 , respectively. To avoid a reduction in DM intake, the NRC (2001) recommends formulating rations for dairy cows with a maximum of $6-7 \%$ EE (DM basis). That is, even in the treatment with SO supplementation, the estimated EE content of the diet consumed was below the maximum limit recommended by the NRC (2001). The absence of effect $(\mathrm{P}>0.05)$ of treatment on the pasture NDF intake within each evaluation period (Table 2) can be considered indicative that the SO supplementation did not affect the digestion of the ingested fibrous fraction and, consequently, did not reduce the pasture DM intake. In addition, as the concentrate DM intake was the same for the two treatments $\left(2.86 \mathrm{~kg} \mathrm{cow}^{-1}\right.$ day $\left.^{-1}\right)$, the absence of effect of SO supplementation on the pasture DM intake was reflected in the observed similarity $(\mathrm{P}>0.05)$ between treatments in total DM intake of the diets within each evaluation period (Table 2).

The higher NDF intakes $(\mathrm{P}<0.0001)$ during the last two periods are a consequence of the lower $(\mathrm{P}<0.0001)$ pasture $\mathrm{DM}$ intake in the first period relative to the others (Table 2 ) because the concentrate DM intakes were similar $(\mathrm{P}>0.05)$ between treatments within each evaluation period. The pasture $\mathrm{CP}$ intake differed $(\mathrm{P}<0.0001)$ among the three periods, with the highest value in the latter (Table 2), mainly attributable to the highest pasture CP content (17.6\% DM; Table 1). In the treatment with SO, the highest levels of PUN and MUN 
$(\mathrm{P}<0.001)$ were found in the third period (Table 3), probably due to the higher pasture CP intake (Table $2)$. No effect $(\mathrm{P}>0.05)$ of lipid supplementation was observed on the PUN and MUN levels (Table 3), whose values were within (PUN $=7-19 \mathrm{mg} \mathrm{dL}^{-1}$ ) or were similar $\left(\mathrm{MUN}=14.4\right.$ to $16.8 \mathrm{mg} \mathrm{dL}^{-1}$ ) to those reported for dairy cows on tropical pastures supplemented with concentrates (LIMA et al., 2004; SANTANA JÚNIOR et al., 2013).

Table 3. Effect of period and supplementation with sunflower oil (SO) on milk urea nitrogen (MUN) and on concentrations of nonesterified fatty acids (NEFA), glucose and urea nitrogen (PUN) in plasma of Holstein x Gyr cows grazing marandu grass.

\begin{tabular}{lccccccc}
\hline & \multicolumn{3}{c}{ Without SO $^{(1)}$} & \multicolumn{3}{c}{ With SO $^{(1)}$} & \multirow{2}{*}{ SEM $^{(3)}$} \\
\cline { 2 - 6 } Item & \multicolumn{3}{c}{ Period $^{(2)}$} & \multicolumn{3}{c}{ Period $^{(2)}$} & \\
\cline { 2 - 6 } & 1 & 2 & 3 & 1 & 2 & 3 & \\
\hline NEFA $\left(\mathrm{mmol} \mathrm{L}^{-1}\right)$ & $0.090 \mathrm{Aa}$ & $0.132 \mathrm{Aa}$ & $0.113 \mathrm{Aa}$ & $0.136 \mathrm{Aa}$ & $0.145 \mathrm{Aa}$ & $0.117 \mathrm{Aa}$ & 0.0216 \\
Glucose $\left(\mathrm{mg} \mathrm{dL}^{-1}\right)$ & $52.7 \mathrm{Ab}$ & $53.6 \mathrm{Ab}$ & $59.3 \mathrm{Aa}$ & $54.5 \mathrm{Ab}$ & $53.4 \mathrm{Ab}$ & $59.9 \mathrm{Aa}$ & 1.9751 \\
PUN $\left(\mathrm{mg} \mathrm{dL}^{-1}\right)^{*}$ & $15.3 \mathrm{Aa}$ & $13.3 \mathrm{Ab}$ & $15.2 \mathrm{Aa}$ & $14.7 \mathrm{Ab}$ & $14.3 \mathrm{Ab}$ & $16.4 \mathrm{Aa}$ & 0.5903 \\
MUN $\left(\mathrm{mg} \mathrm{dL}^{-1}\right)^{*}$ & $17.6 \mathrm{Aa}$ & $14.7 \mathrm{Ab}$ & $17.8 \mathrm{Aa}$ & $16.6 \mathrm{Ab}$ & $16.3 \mathrm{Ab}$ & $18.5 \mathrm{Aa}$ & 0.6459 \\
\hline
\end{tabular}

*Significant interaction between Lipid supplementation*Period $(\mathrm{P}<0.05)$.

${ }^{(1)}$ Within the same treatment (inclusion or not of $\left.\mathrm{SO}\right)$, lowercase letters indicate no significant difference $(\mathrm{P}>0.05)$ among periods; ${ }^{(2)}$ Within the same period, uppercase letters indicate no significant difference $(\mathrm{P}>0.05)$ among treatments; ${ }^{(3)}$ SEM - standard error of the mean.

A treatment $(\mathrm{P}<0.0001)$, period $(\mathrm{P}=0.0003)$ and interaction effect $(\mathrm{P}=0.0014)$ on total $\mathrm{EE}$ intake was observed. Relative to the treatment with lipid supplementation, the SO inclusion was responsible for the similarity $(\mathrm{P}>0.05)$ in $\mathrm{EE}$ intakes between periods, whereas in the treatment without $\mathrm{SO}$, the differences $(\mathrm{P}=0.0003)$ were a direct consequence of the DM intakes (Table 2) and the pasture EE contents (Table 1). In all three periods, the EE intake was higher $(\mathrm{P}<0.0001)$ in the SO treatment compared to the control (Table 2), as well as the fecal EE content (5.4\% versus $7.8 \% \mathrm{DM})$. An effect $(\mathrm{P}<0.001)$ of $\mathrm{SO}$ supplementation and period on the intakes of stearic (C18:0), linoleic and oleic acids was observed, whereas the SLP*DAY interaction was significant $(\mathrm{P}=0.0002)$ only for oleic acid intake (Table 2). The higher linoleic acid intake in the three periods in cows supplemented with lipid is explained by the $66.5 \%$ linoleic acid in SO. The $\alpha$-linolenic acid derives mainly from forage (Table 1 ), and since no difference existed in pasture DM intake between treatments, the intake of this FA did not change (Table 2).

No interaction (SLP*DAY) nor effect $(\mathrm{P}>0.05)$ of SO supplementation was observed for NEFA and plasma glucose concentrations (Table 3 ). The NEFA contents were within the range $(0.073-0.248 \mathrm{mmol}$ $\mathrm{L}^{-1}$ ) reported by Silva et al. (2017), who, in turn, observed higher concentrations of plasma glucose (60.7 to $65.0 \mathrm{mg} \mathrm{dL}^{-1}$ ) in cows with $93 \pm 13$ days in milk that were grazing on marandu grass and supplemented with concentrate.

Additionally, no effect $(\mathrm{P}>0.05)$ of the SLP*DAY interaction or $\mathrm{SO}$ inclusion on milk production and its components, and on milk protein and total solids contents was observed (Table 4). Higher lactose content was observed in the milk of cows receiving $\mathrm{SO}$ in the $2^{\text {nd }}$ and $3^{\text {rd }}$ period, although this result could not be explained by the plasma glucose concentration, which was similar between treatments in the three periods (Table 3). A period 
effect $(\mathrm{P}<0.05)$ was observed on the milk fat and total solids contents, but no effect $(\mathrm{P}>0.05)$ was observed on the milk protein and lactose contents (Table 4). As a reflection of the progression in lactation, and regardless of the treatment, milk yield, and fat, protein and total solids production was always higher $(\mathrm{P}<0.05)$ in the first period in comparison to the others, which were similar $(\mathrm{P}>0.05)$ to each other (Table 4).

Table 4. Effect of period and supplementation with sunflower oil (SO) on milk yield and composition in Holstein $\mathrm{x}$ Gyr cows grazing on marandu grass.

\begin{tabular}{|c|c|c|c|c|c|c|c|}
\hline \multirow{3}{*}{ Variable } & \multicolumn{3}{|c|}{ Without $\mathrm{SO}^{(1)}$} & \multicolumn{3}{|c|}{ With $\mathrm{SO}^{(1)}$} & \multirow{3}{*}{$\mathrm{SEM}^{(3}$} \\
\hline & \multicolumn{3}{|c|}{ Period $^{(2)}$} & \multicolumn{3}{|c|}{ Period $^{(2)}$} & \\
\hline & 1 & 2 & 3 & 1 & 2 & 3 & \\
\hline \multicolumn{8}{|c|}{ Yield $\left(\mathrm{kg} \mathrm{cow}^{-1}\right.$ day $\left.^{-1}\right)$} \\
\hline Milk & $14.6 \mathrm{Aa}$ & $11.7 \mathrm{Ab}$ & $12.2 \mathrm{Ab}$ & $13.8 \mathrm{Aa}$ & $11.9 \mathrm{Ab}$ & $10.6 \mathrm{Ab}$ & 0.9270 \\
\hline $\mathrm{FCM}^{(4)}$ & 15.3 Aa & $12.8 \mathrm{Ab}$ & $13.1 \mathrm{Ab}$ & $13.7 \mathrm{Aa}$ & $11.7 \mathrm{Ab}$ & $11.4 \mathrm{Ab}$ & 1.3884 \\
\hline Fat & $0.556 \mathrm{Aa}$ & $0.476 \mathrm{Ab}$ & $0.486 \mathrm{Ab}$ & $0.477 \mathrm{Aa}$ & $0.401 \mathrm{Ab}$ & $0.417 \mathrm{Ab}$ & 0.0591 \\
\hline Protein & $0.446 \mathrm{Aa}$ & $0.363 \mathrm{Ab}$ & $0.381 \mathrm{Ab}$ & $0.432 \mathrm{Aa}$ & $0.371 \mathrm{Ab}$ & $0.334 \mathrm{Ab}$ & 0.0337 \\
\hline Lactose & $0.642 \mathrm{Aa}$ & $0.510 \mathrm{Ab}$ & $0.535 \mathrm{Ab}$ & $0.630 \mathrm{Aa}$ & $0.548 \mathrm{Ab}$ & $0.482 \mathrm{Ac}$ & 0.0418 \\
\hline Total solids & $1.761 \mathrm{Aa}$ & $1.449 \mathrm{Ab}$ & $1.497 \mathrm{Ab}$ & $1.654 \mathrm{Aa}$ & $1.423 \mathrm{Ab}$ & $1.326 \mathrm{Ab}$ & 0.1349 \\
\hline \multicolumn{8}{|c|}{ Composition (\%) } \\
\hline Fat & $3.80 \mathrm{Ab}$ & $4.06 \mathrm{Aab}$ & $4.14 \mathrm{Aa}$ & $3.46 \mathrm{Ab}$ & $3.44 \mathrm{Bb}$ & $3.93 \mathrm{Aa}$ & 0.2041 \\
\hline Protein & $3.07 \mathrm{Aa}$ & $3.11 \mathrm{Aa}$ & $3.21 \mathrm{Aa}$ & $3.13 \mathrm{Aa}$ & $3.17 \mathrm{Aa}$ & $3.16 \mathrm{Aa}$ & 0.1150 \\
\hline Lactose & $4.40 \mathrm{Aa}$ & $4.38 \mathrm{Ba}$ & $4.37 \mathrm{Ba}$ & $4.56 \mathrm{Aa}$ & $4.61 \mathrm{Aa}$ & $4.53 \mathrm{Aa}$ & 0.0683 \\
\hline Total solids & $12.08 \mathrm{Ab}$ & $12.41 \mathrm{Aa}$ & $12.63 \mathrm{Aa}$ & $11.99 \mathrm{Ab}$ & 12.09 Aab & $12.49 \mathrm{Aa}$ & 0.3122 \\
\hline
\end{tabular}

${ }^{(1)}$ Within the same treatment (inclusion or not of $\mathrm{SO}$ ), lowercase letters indicate no significant difference $(\mathrm{P}>0.05)$ among periods; ${ }^{(2)}$ Within the same period, uppercase letters indicate no significant difference $(\mathrm{P}>0.05)$ between treatments; ${ }^{(3)}$ SEM - standard error of the mean; ${ }^{(4)}$ FCM $($ RIBEIRO et al., 2014) $=$ Fat-corrected milk $=(0.432+0.1625 *$ milk fat $) *$ milk yield.

The higher intakes of stearic, linoleic and oleic acids in the treatment with SO (Table 2) did not result in the appearance of these FA in plasma, and regardless of treatment, those present in higher concentrations were stearic, linoleic, oleic, palmitic and $\alpha$-linolenic acids (Table 5). However, the lower content of odd- and branched-chain FAs (OBCFA) in the plasma of cows receiving the SO was notable (Table 5). The OBCFAs are found in lipid membranes of ruminal bacteria, and dietary supplementation with oils rich in linoleic acid may alter the ruminal fermentation pattern, reducing the flow of bacteria to the duodenum, resulting in lower levels of OBCFA in the plasma and milk (VLAEMINCK et al., 2006). 
Table 5. Effect of dietary inclusion of sunflower oil (SO) on plasma concentrations of fatty acids (FA) in Holstein $x$ Gyr cows grazing on marandu grass.

\begin{tabular}{lcccc}
\hline \multirow{2}{*}{ Fatty acid $\left(\mathrm{g} 100 \mathrm{~g}^{-1} \mathrm{FA}\right)^{(1)}$} & \multicolumn{2}{c}{ Treatment } & \multirow{2}{*}{ SEM $^{(2)}$} & \multirow{2}{*}{ P-value } \\
\cline { 2 - 3 } C16:0 & Without SO & With SO & & \\
C18:0 & 9.609 & 9.550 & 0.5095 & 0.9311 \\
trans-11 C18:1 & 24.308 & 23.616 & 0.5245 & 0.2188 \\
cis-9 C18:1 & 1.127 & 1.067 & 0.0712 & 0.4664 \\
cis-9, cis-12 C18:2 & 15.564 & 14.479 & 0.4810 & 0.1499 \\
cis-9, cis-12, cis-15 C18:3 & 17.150 & 17.693 & 0.7733 & 0.4675 \\
cis-9, trans-11 CLA & 2.674 & 1.964 & 0.2315 & 0.0581 \\
Odd- and branched-chain fatty acids & 0.206 & 0.249 & 0.0169 & 0.1175 \\
\hline
\end{tabular}

${ }^{(1)}$ Values observed at the $62^{\text {nd }}$ day of concentrate supply; ${ }^{(2)} \mathrm{SEM}-$ standard error of the mean.

An effect $(\mathrm{P}<0.05)$ of $\mathrm{SO}$ supplementation on milk fat was observed for most FAs (Table 6), except for trans-palmitoleic acid (trans-9 C16:1; $\mathrm{P}=0.06)$ and dihomo- $\gamma$-linoleic acid (cis-8, cis-11, cis-14 C20:3; $\mathrm{P}=0.09$ ).

The higher $(\mathrm{P}<0.05)$ intakes of linoleic and oleic acids in the treatment with SO (Table 2) promoted substantial changes in the typical ruminal $\mathrm{BH}$ pathways of unsaturated-C18 FAs. The common final product in these routes is stearic acid, and the main intermediates are trans- 6 to trans- 16 C18:1, cis-10 to cis-12 C18:1 and cis-15 C18:1 FAs, as well as conjugated and nonconjugated isomers of linoleic acid (SHINGFIELD et al., 2010; BUCCIONI et al., 2012). In fact, supplementation with $\mathrm{SO}$ was responsible for the intense ruminal $\mathrm{BH}$ of the linoleic and oleic acids and, to a lesser extent, of the $\alpha$-linolenic acid. Supplementation promoted an increase in rumen-derived FA, such as elaidic (trans-9 C18:1), vaccenic, rumenic, trans-10 C18:1, trans-9, cis-11 CLA and trans-10, cis-12 CLA, as well as trans-C18:1 and nonconjugated isomers of linoleic acid (Table 6). The SO supplementation reduced $(\mathrm{P}<0.0001)$ the content of OBCFA in the milk (Table 6 ), indicating the occurrence of adaptive changes in the ruminal environment of cows. The secreted OBCFAs in milk are mainly originate from de novo-synthesized FAs by ruminal bacteria and incorporated into membrane lipids of these bacteria. Then, the contents of these FA in milk fat may be indicative of the activity and growth of these microorganisms in the rumen (VLAEMINCK et al., 2006). Temporal trends revealed an effect $(\mathrm{P}<0.0001)$ of sampling day at 62 days of $\mathrm{SO}$ supplementation (data not shown) on contents of OBCFAs in milk, indicating that, in fact, the ruminal environment was gradually modified in response to the dietary intake of FA from the SO. 


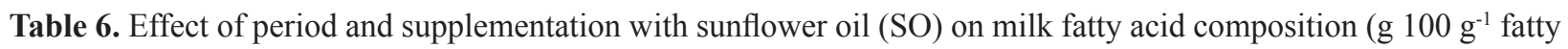
acids) in Holstein x Gyr cows grazing on marandu grass.

\begin{tabular}{|c|c|c|c|c|c|c|c|}
\hline \multirow{3}{*}{ Variable } & \multicolumn{3}{|c|}{ Without SO ${ }^{(1)}$} & \multicolumn{3}{|c|}{ With SO ${ }^{(1)}$} & \multirow{3}{*}{$\mathrm{SEM}^{(3)}$} \\
\hline & \multicolumn{3}{|c|}{ Period $^{(2)}$} & \multicolumn{3}{|c|}{ Period $^{(2)}$} & \\
\hline & 1 & 2 & 3 & 1 & 2 & 3 & \\
\hline \multicolumn{8}{|c|}{ Saturated even-chain fatty acids } \\
\hline$\Sigma 4 \leq \mathrm{C} \leq 10^{*}$ & $8.99 \mathrm{Aa}$ & $8.27 \mathrm{Ab}$ & $8.76 \mathrm{Aa}$ & $6.74 \mathrm{Ba}$ & $5.57 \mathrm{Bb}$ & $5.79 \mathrm{Bb}$ & 0.270 \\
\hline $\mathrm{C} 12: 0^{*}$ & $2.59 \mathrm{Aa}$ & $2.51 \mathrm{Aa}$ & $2.67 \mathrm{Aa}$ & $1.51 \mathrm{Ba}$ & $1.27 \mathrm{Bb}$ & $1.32 \mathrm{Bb}$ & 0.123 \\
\hline $\mathrm{C} 14: 0^{*}$ & $9.56 \mathrm{Aa}$ & $9.40 \mathrm{Aa}$ & $9.61 \mathrm{Aa}$ & $6.77 \mathrm{Ba}$ & $6.07 \mathrm{Bb}$ & $6.26 \mathrm{Bb}$ & 0.375 \\
\hline C16:0 & $27.5 \mathrm{Aa}$ & $27.4 \mathrm{Aa}$ & $27.9 \mathrm{Aa}$ & $20.1 \mathrm{Ba}$ & $19.8 \mathrm{Ba}$ & $20.1 \mathrm{Ba}$ & 0.548 \\
\hline$\Sigma 12 \leq \mathrm{C} \leq 16^{*}$ & $39.6 \mathrm{Aa}$ & $39.3 \mathrm{Aa}$ & $40.2 \mathrm{Aa}$ & $28.4 \mathrm{Ba}$ & $27.1 \mathrm{Bb}$ & $27.7 \mathrm{Bb}$ & 0.758 \\
\hline $\mathrm{C} 18: 0^{*}$ & $11.7 \mathrm{Ba}$ & $12.8 \mathrm{Ba}$ & $11.5 \mathrm{Ba}$ & $15.1 \mathrm{Ab}$ & 17.4 Aa & $17.5 \mathrm{Aa}$ & 0.758 \\
\hline$\Sigma 18 \leq \mathrm{C} \leq 24$ & $11.9 \mathrm{Ba}$ & $13.0 \mathrm{Ba}$ & $11.7 \mathrm{Ba}$ & $15.3 \mathrm{Ab}$ & $17.7 \mathrm{Aa}$ & $17.7 \mathrm{Aa}$ & 0.766 \\
\hline$\Sigma 4 \leq \mathrm{C} \leq 24$ & $60.6 \mathrm{Aa}$ & $60.6 \mathrm{Aa}$ & $60.7 \mathrm{Aa}$ & $50.4 \mathrm{Ba}$ & $50.3 \mathrm{Ba}$ & $51.2 \mathrm{Ba}$ & 1.068 \\
\hline \multicolumn{8}{|c|}{ cis/trans even-chain monounsaturated fatty acids } \\
\hline trans $-9 \mathrm{C} 16: 1$ & $0.10 \mathrm{Aa}$ & $0.09 \mathrm{Aa}$ & $0.06 \mathrm{Ab}$ & $0.12 \mathrm{Aa}$ & $0.10 \mathrm{Aa}$ & $0.07 \mathrm{Ab}$ & 0.009 \\
\hline cis-9 C18:1 & $21.7 \mathrm{Ba}$ & $21.2 \mathrm{Ba}$ & $21.7 \mathrm{Ba}$ & $29.8 \mathrm{Aa}$ & $29.1 \mathrm{Aa}$ & $30.0 \mathrm{Aa}$ & 0.788 \\
\hline trans-9 C18:1* & $0.18 \mathrm{Ba}$ & $0.18 \mathrm{Ba}$ & $0.19 \mathrm{Ba}$ & $0.41 \mathrm{Ab}$ & $0.44 \mathrm{Aa}$ & $0.35 \mathrm{Ac}$ & 0.013 \\
\hline trans-10 C18:1* & $0.26 \mathrm{Ba}$ & $0.24 \mathrm{Ba}$ & $0.25 \mathrm{Ba}$ & $0.67 \mathrm{Aa}$ & $0.60 \mathrm{Aab}$ & $0.47 \mathrm{Ab}$ & 0.049 \\
\hline trans-11 C18:1* & $1.83 \mathrm{Ba}$ & $1.97 \mathrm{Ba}$ & $2.03 \mathrm{Ba}$ & $2.40 \mathrm{Ab}$ & $3.23 \mathrm{Aa}$ & $2.80 \mathrm{Ab}$ & 0.145 \\
\hline trans $-\mathrm{C} 18: 1^{(4) *}$ & $3.17 \mathrm{Ba}$ & $3.33 \mathrm{Ba}$ & $3.34 \mathrm{Ba}$ & $5.51 \mathrm{Ab}$ & $6.47 \mathrm{Aa}$ & $5.44 \mathrm{Ab}$ & 0.181 \\
\hline \multicolumn{8}{|c|}{ Conjugated (CLA) and nonconjugated (NCLA) isomers of linoleic acid* } \\
\hline$\Sigma \mathrm{NCLA}^{(5)}$ & $0.09 \mathrm{Ba}$ & $0.10 \mathrm{Ba}$ & $0.10 \mathrm{Ba}$ & $0.14 \mathrm{Ab}$ & $0.18 \mathrm{Aa}$ & $0.14 \mathrm{Ab}$ & 0.008 \\
\hline cis-9 trans-11 CLA & $0.98 \mathrm{Bab}$ & $0.89 \mathrm{Bb}$ & $1.05 \mathrm{Ba}$ & $1.41 \mathrm{Aa}$ & $1.48 \mathrm{Aa}$ & $1.38 \mathrm{Aa}$ & 0.102 \\
\hline trans-9 cis-11 CLA & $0.015 \mathrm{Ba}$ & $0.016 \mathrm{Ba}$ & $0.019 \mathrm{Aa}$ & $0.028 \mathrm{Aa}$ & $0.024 \mathrm{Aab}$ & $0.022 \mathrm{Ab}$ & 0.002 \\
\hline trans-10 cis 12 CLA & $0.004 \mathrm{Bb}$ & $0.003 \mathrm{Bb}$ & $0.006 \mathrm{Aa}$ & $0.007 \mathrm{Aa}$ & $0.008 \mathrm{Aa}$ & $0.006 \mathrm{Aa}$ & 0.001 \\
\hline \multicolumn{8}{|c|}{ Odd- and branched-chain fatty acids (OBCFA) } \\
\hline$\Sigma \mathrm{OLCFA}^{(6)}$ & $2.36 \mathrm{Ab}$ & $2.56 \mathrm{Aa}$ & $2.31 \mathrm{Ab}$ & $1.88 \mathrm{Bb}$ & $1.96 \mathrm{Ba}$ & $1.83 \mathrm{Bb}$ & 0.036 \\
\hline$\Sigma$ anteiso $\mathrm{FA}^{(7)}$ & $0.74 \mathrm{Aa}$ & $0.75 \mathrm{Aa}$ & $0.69 \mathrm{Ab}$ & $0.59 \mathrm{Ba}$ & $0.58 \mathrm{Ba}$ & $0.54 \mathrm{Bb}$ & 0.022 \\
\hline$\Sigma$ iso $\mathrm{FA}^{(8)}$ & $1.49 \mathrm{Aa}$ & $1.58 \mathrm{Aa}$ & $1.47 \mathrm{Aa}$ & $1.27 \mathrm{Ba}$ & $1.33 \mathrm{Ba}$ & $1.33 \mathrm{Ba}$ & 0.030 \\
\hline$\Sigma \mathrm{OBCFA}^{(9)}$ & $4.59 \mathrm{Ab}$ & $4.89 \mathrm{Aa}$ & $4.46 \mathrm{Ab}$ & $3.75 \mathrm{Bb}$ & $3.87 \mathrm{Ba}$ & $3.70 \mathrm{Bb}$ & 0.071 \\
\hline \multicolumn{8}{|c|}{ Long-chain polyunsaturated fatty acids } \\
\hline Linoleic & $0.82 \mathrm{Ba}$ & $0.95 \mathrm{Ba}$ & $0.85 \mathrm{Ba}$ & $1.12 \mathrm{Aa}$ & $1.16 \mathrm{Aa}$ & $1.18 \mathrm{Aa}$ & 0.056 \\
\hline$\alpha$-linolenic & $0.46 \mathrm{Aa}$ & $0.44 \mathrm{Ab}$ & $0.44 \mathrm{Ab}$ & $0.42 \mathrm{Ba}$ & $0.37 \mathrm{Bb}$ & $0.38 \mathrm{Bb}$ & 0.020 \\
\hline C20:3 $\operatorname{DGLA}^{(10)}$ & $0.12 \mathrm{Aa}$ & $0.12 \mathrm{Aa}$ & $0.11 \mathrm{Aa}$ & $0.12 \mathrm{Aa}$ & $0.12 \mathrm{Aa}$ & $0.12 \mathrm{Aa}$ & 0.004 \\
\hline C20:4 ARA*(11) & $0.10 \mathrm{Aa}$ & $0.10 \mathrm{Aa}$ & $0.09 \mathrm{Aa}$ & $0.08 \mathrm{Ba}$ & $0.07 \mathrm{Bb}$ & $0.08 \mathrm{Ba}$ & 0.004 \\
\hline C20:5 EPA ${ }^{(12)}$ & $0.04 \mathrm{Aa}$ & $0.04 \mathrm{Aa}$ & $0.04 \mathrm{Aa}$ & $0.03 \mathrm{Ba}$ & $0.03 \mathrm{Ba}$ & $0.03 \mathrm{Ba}$ & 0.002 \\
\hline $\mathrm{C} 22: 5 \mathrm{DPA}^{(13)}$ & $0.07 \mathrm{Aa}$ & $0.07 \mathrm{Aab}$ & $0.07 \mathrm{Ab}$ & $0.06 \mathrm{Ba}$ & $0.06 \mathrm{Bab}$ & $0.05 \mathrm{Bb}$ & 0.003 \\
\hline
\end{tabular}

*Significant interaction between Lipid supplementation*Period $(\mathrm{P}<0.05)$.

${ }^{(1)}$ Within the same treatment (inclusion or not of SO), lowercase letters indicate no significant difference $(\mathrm{P}>0.05)$ among periods; ${ }^{(2)}$ Within the same period, uppercase letters indicate no significant difference $(\mathrm{P}>0.05)$ among treatments; ${ }^{(3)} \mathrm{SEM}-\mathrm{standard}$ error of the mean; ${ }^{(4)} \Sigma \mathrm{FA}$ trans-C18:1 = trans-4 C18:1 + trans-5 C18:1 + trans 6-8 C18:1 + trans-9 C18:1 + trans-10 C18:1 + trans-11 
continuation

C18:1 + trans-12 C18:1 + trans-13 and trans-14 C18:1 + trans-16 C18:1; ${ }^{(5)} \Sigma$ NCLA $=$ trans-9, trans-12 C18:2 + cis-9, trans-12 C18:2 + trans-9, cis-12 C18:2; ${ }^{(6)}$ OLCFA (odd-linear-chain FA) $=\mathrm{C} 5: 0+\mathrm{C} 7: 0+\mathrm{C} 9: 0+\mathrm{C} 11: 0+\mathrm{C} 15: 0+\mathrm{C} 17: 0+$ cis-9 C17:1 $+\mathrm{C} 21: 0+\mathrm{C} 23: 0 ;{ }^{(7)} \Sigma$ anteiso $\mathrm{FA}=$ anteiso $\mathrm{C} 15: 0 ;{ }^{\left({ }^{8}\right.} \boldsymbol{\Sigma}$ iso $\mathrm{FA}=$ iso $\mathrm{C} 14: 0+$ iso $\mathrm{C} 15: 0+$ iso $\mathrm{C} 16: 0+$ iso $\mathrm{C} 17: 0+$ iso $\mathrm{C} 18: 0 ;{ }^{(9)}$ $\Sigma$ OBCFA $=\Sigma$ anteiso FA $+\Sigma$ iso FA $+\Sigma$ OLCFA; ${ }^{(10)}$ DGLA $=$ dihomo- $\gamma$-linoleic acid $\left(\right.$ cis-8, cis-11, cis-14 C20:3); ${ }^{(11)}$ ARA $=$ araquidonic acid (cis-5, cis-8, cis-11, cis-14 C20:4); ${ }^{(12)} \mathrm{EPA}=$ eicosapentaenoic acid (cis-5, cis-8, cis-11, cis-14, cis-17 C20:5); ${ }^{(13)}$ DPA = docosapentaenoic acid (cis-7, cis-10, cis-13, cis-16, cis-19 C22:5).

Areduction $(\mathrm{P}<0.0001)$ in the contents of saturated FAs with an even number of carbons $\mathrm{C} 4: 0$ to $\mathrm{C} 16: 0$ was also observed in response to SO supplementation (Table 6). These FAs originate mostly from de novo synthesis in the mammary gland, and as discussed by Mourthé et al. (2015), the reduction of their milk contents may be related to the inhibition of mRNA abundance and/or the activity of enzymes involved in de novo FA synthesis in response to the higher intake of unsaturated FAs (Table 2). In addition, the selective and preferential incorporation of long chain FAs in milk fat triglycerides to the detriment of those with short and medium saturated chains, is also be associated with this result. The lower availability of acetate and $\beta$-hydroxybutyrate in the mammary gland for de novo FA synthesis in response to possible deleterious effects of $\mathrm{SO}$ on the fermentation of fibrous carbohydrates from pasture, may also be considered. Nonetheless, there are indications of its minor importance in this process (e.g., low EE dietary content and intense ruminal $\mathrm{BH}$ of FA, indicated by high stearic acid content in milk of cows receiving SO). Ribeiro et al. (2014) and Mourthé et al. (2015) also reported a significant reduction $(\mathrm{P}<0.05)$ in $\mathrm{C} 4: 0$ to $\mathrm{C} 16: 0$ FA contents in milk of cows fed SO in chopped elephant grassbased diets or managed under grazing on marandu grass supplemented with roasted soybean. In response to increased intake (Table 2) and the probable increased rumen flow because of the competition between $\mathrm{BH}$ versus passage rate, $\mathrm{SO}$ supplementation increased the levels of oleic and linoleic acids in the milk fat (Table 6). The absence $(\mathrm{P}>0.05)$ of effect of SO supplementation on the stearoyl-CoA desaturase activity indices, especially on the oleic:stearic ratio (Table 7), indicates the importance of the contribution of oleic acid captured from the plasma by the mammary gland for its secretion in milk.

Table 7. Effect of period and supplementation with sunflower oil (SO) on activity indices (product-to-precursor ratio) of the stearoyl-CoA desaturase enzyme in the mammary gland of Holstein x Gyr cows grazing on marandu grass.

\begin{tabular}{lccccccc}
\hline & \multicolumn{3}{c}{ Without SO $^{(2)}$} & \multicolumn{3}{c}{ With SO $^{(2)}$} & \multirow{2}{*}{ SEM $^{(4)}$} \\
\cline { 2 - 6 } Desaturase indices & \multicolumn{3}{c}{ Period $^{(3)}$} & \multicolumn{3}{c}{ Period $^{(3)}$} & \\
\cline { 2 - 7 } & 1 & 2 & 3 & 1 & 2 & 3 & \\
\hline cis-9 C14:1/C14:0 & $0.092 \mathrm{Aa}$ & $0.078 \mathrm{Ab}$ & $0.094 \mathrm{Aa}$ & $0.097 \mathrm{Aa}$ & $0.078 \mathrm{Ab}$ & $0.084 \mathrm{Ab}$ & 0.0080 \\
cis-9 C16:1/C16:0 & $0.064 \mathrm{Aa}$ & $0.063 \mathrm{Aa}$ & $0.064 \mathrm{Aa}$ & $0.067 \mathrm{Aa}$ & $0.062 \mathrm{Ab}$ & $0.060 \mathrm{Ab}$ & 0.0039 \\
Oleic/Stearic & $0.649 \mathrm{Aab}$ & $0.624 \mathrm{Ab}$ & $0.652 \mathrm{Aa}$ & $0.664 \mathrm{Aa}$ & $0.626 \mathrm{Ab}$ & $0.633 \mathrm{Ab}$ & 0.0159 \\
Rumenic/Vaccenic & $0.344 \mathrm{Aa}$ & $0.310 \mathrm{Ab}$ & $0.343 \mathrm{Aa}$ & $0.369 \mathrm{Aa}$ & $0.316 \mathrm{Ab}$ & $0.334 \mathrm{Ab}$ & 0.0150 \\
\hline
\end{tabular}

${ }^{(1)}$ Calculated according to Silva et al. (2017); (2)Within the same treatment (inclusion or not of SO), lowercase letters indicate no significant difference $(\mathrm{P}>0.05)$ among periods; ${ }^{(3)}$ Within the same period, uppercase letters indicate no significant difference $(\mathrm{P}>0.05)$ between treatments; ${ }^{(4)} \mathrm{SEM}-$ standard error of the mean. 
For the linoleic acid, the average increase of $\sim 32 \%$ in the milk of cows fed SO (Table 6) was not proportional to their intake (on average, $\sim 51 \%$ higher in SO treatment; Table 2), indicating an intense ruminal $\mathrm{BH}$. In fact, this can be proven by the presence of several rumen-derived FAs, as already discussed, as well as by the expressive (Table 6) and fast (Figure 1) increase in stearic acid content in milk in response to SO supplementation. The high levels of stearic acid in the milk of cows receiving SO (on average, $\sim 39 \%$ higher than the control treatment; Table 6) indicate that the ruminal environment did not limit the activity of microbiota involved in the $\mathrm{BH}$ reactions of unsaturated FA, a typical response in cattle managed under tropical grasses with high NDF contents. The contents of stearic acid in the milk of cows fed SO (Table 6) can be considered high and were similar to those reported by Ribeiro et al. (2014) of 15.7 and $16.6 \mathrm{~g}$ $100 \mathrm{~g}^{-1}$ FA, respectively, in milk of Holstein cows receiving $2.5 \%$ and $3.7 \% \mathrm{SO}$ (on a DM basis) in chopped elephant grass-based diets. Regarding the similarity $(\mathrm{P}>0.05)$ between the treatments relative to $\alpha$-linolenic acid total intake (Table 2), the highest content of this FA in the milk of nonsupplemented cows (on average, $\sim 15 \%$ higher than treatment with $\mathrm{SO}$; Table 6) is another result that indicates the intensification of the ruminal $\mathrm{BH}$ of unsaturated FAs when SO was included. As reported by Buccioni et al. (2012), forage lipids, which are protected from lipolysis and ruminal $\mathrm{BH}$ by cell structures, are less degradable than those present in free vegetable oils. Quadratic effects $(\mathrm{P}<0.05)$ were observed for the supplementation with $\mathrm{SO}$ on the contents of stearic and $\alpha$-linolenic acids in milk. The highest concentrations in milk for stearic acid (18.2 g 100 $\left.\mathrm{g}^{-1} \mathrm{FA}\right)$ and the lowest for $\alpha$-linolenic acid $(0.34 \mathrm{~g}$ $100 \mathrm{~g}^{-1} \mathrm{FA}$ ) were estimated, respectively, at 45 and 42 days of SO supply (Figure 1).

Among the isomers of the trans-C18:1 intermediates of ruminal $\mathrm{BH}$ of unsaturated FAs and of interest to human health, we can highlight the vaccenic, elaidic and trans-10 C18:1 FAs. The latter two have been associated with deleterious effects on cardiovascular health (ALMEIDA et al., 2014), and therefore, the reduction of their milk contents is desirable. However, SO supplementation promoted an increase $(\mathrm{P}<0.0001)$ in the contents of these two FAs in milk (Table 6). On the other hand, the vaccenic acid, which was the main trans-C18:1 isomer (Table 6), is the precursor for synthesis of rumenic acid on the order of $64 \%$ to $97 \%$ in bovine milk (SHINGFIELD et al., 2010). Therefore, diets that promote an increase in the supply of vaccenic acid from the rumen to the mammary gland normally result in higher concentrations of rumenic acid in milk. In addition, $19 \%$ of the consumed vaccenic acid is converted to rumenic acid in human tissues (TURPEINEN et al., 2002). The SO supplementation promoted $\sim 45 \%$ of increase in the milk content of vaccenic acid (Table 6). The regression of milk contents (g $100 \mathrm{~g}^{-1} \mathrm{FA}$ ) of rumenic versus vaccenic acids demonstrates the close association between these FAs $\left(\hat{y}=0.35558^{*} \mathrm{x}+0.35297 ; \mathrm{r}^{2}=0.47\right.$; $\mathrm{P}<0.0001$ ), which was also reported by Mourthé et al. (2015) in the milk of cows grazing on marandu grass supplemented with roasted soybean. This can be better visualized in temporal trends, considering the quadratic behaviors observed for the contents of these two FAs as a function of elapsed time in days from the beginning of the SO concentrate supplementation (Figure 1). Vaccenic and rumenic acid contents in milk of cows not supplemented with SO concentrate (Table 6) are within the range of values compiled by Lopes et al. (2015) from 10 studies with cows in tropical pastures not supplemented with lipid sources. However, the values are higher than that normally observed $(\leq$

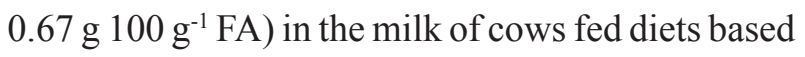
on corn silage and concentrates without ingredients rich in $\alpha$-linolenic and linoleic FAs (LOPES et al., 2011). The results of our study demonstrate the high nutraceutical potential of milk produced in pasture. On the other hand, the contents of vaccenic and rumenic acids in milk of cows receiving SO (Table 6) were lower than those reported by Ribeiro et al. 


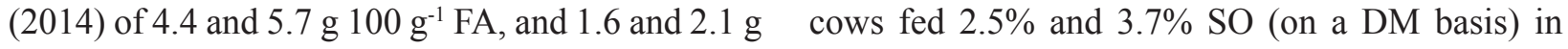
$100 \mathrm{~g}^{-1} \mathrm{FA}$, respectively, in the milk fat of Holstein their chopped elephant grass-based diets.

Figure 1. Fat (\%) and fatty acid content $\left(\mathrm{g} 100 \mathrm{~g}^{-1} \mathrm{FA}\right)$ in the milk of cows grazing on marandu grass as a function of elapsed time (in days) since the beginning of concentrate supply with inclusion $(\boldsymbol{\Lambda}$......) or not ( $\mathbf{\square}-----)$ of sunflower oil.
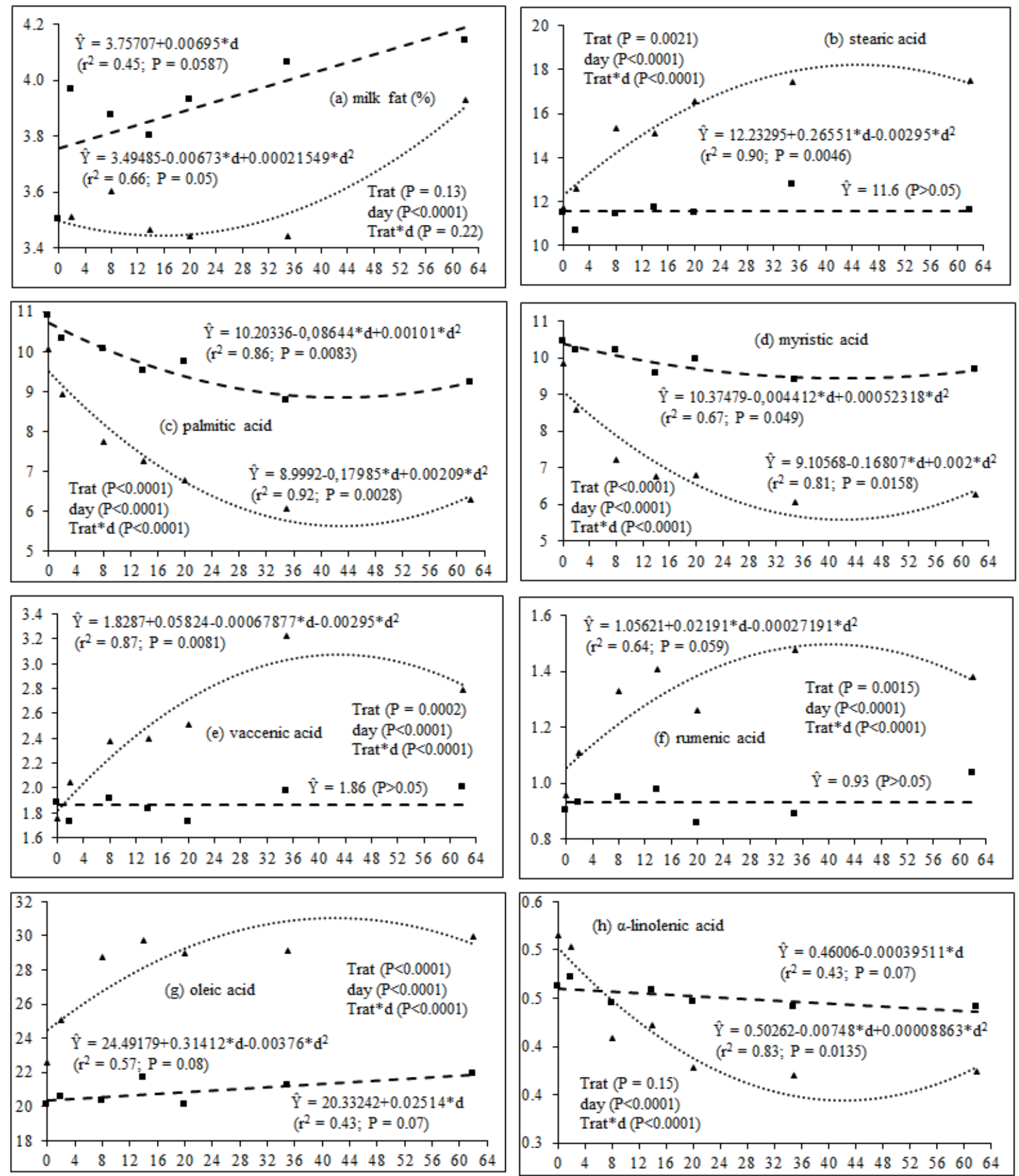

Semina: Ciências Agrárias, Londrina, v. 39, n. 6, p. 2581-2596, nov./dez. 2018 
As previously discussed, trans-9, cis-11 CLA and trans-10, cis-12 CLA are produced in the rumen from $\mathrm{BH}$ of linoleic and $\alpha$-linolenic acids, and the increase in their concentrations in milk is associated with milk fat depression (SHINGFIELD et al., 2010; BUCCIONI et al., 2012). In periods 1 and 2, higher levels $(\mathrm{P}<0.05)$ of these two CLAs were observed in the milk of cows fed SO (Table 6), whereas in the last period no difference between treatments (Table 6), indicating a possible adaptation of the microbiota to the contribution of unsaturated FA in the rumen. Considering the 62 days of trial, temporal trends revealed no linear or quadratic effect $(\mathrm{P}>0.05)$ for the content of these FAs in the milk fat of cows fed concentrate with SO. The milk fat contents in the $1^{\text {st }}$ and $3^{\text {rd }}$ periods were similar $(\mathrm{P}>0.05)$ between treatments (Table 4). Temporal trends revealed a quadratic effect $(\mathrm{P}=0.05)$ for milk fat content for the treatment with $\mathrm{SO}$, with a minimum value $(3.44 \%)$ estimated at 16 days of lipid supplementation, reaching 3.93\% after 62 days of SO supply (Figure 1). From these results, the increases in these two CLA isomers in the SO treatment (Table 6) probably were not sufficient to promote milk fat depression, and in fact, no correlation $(\mathrm{P}>0.05)$ existed between these variables. The difference $(\mathrm{P}<0.05)$ between the first and last period (Table 2) in the milk fat content of cows fed SO can be explained by the possible adaptation of the microbiota to the contribution of unsaturated FA in the rumen. At the beginning of supplementation, the SO probably promoted a change in the ruminal $\mathrm{BH}$ of FA, reducing the milk fat content, and with the adaptation of microbiota, a gradual increase was observed in the milk fat content.

The milk fat of cows fed SO had better nutritional quality, since there was a reduction $(\mathrm{P}<0.0001)$ in the IA and IT, and an increase $(\mathrm{P}<0.0001)$ in the $\mathrm{h} / \mathrm{H}$ FA ratio (Table 8 ). This can be attributed mainly to the decrease in the milk fat contents of the hypercholesterolemic lauric, myristic and palmitic FAs (FAO, 2010), and the concomitant increase in oleic acid content (Table 6), as well as, specifically considering IA and IT, the increase $(\mathrm{P}=0.0009)$ in the contents of cis $\omega-6$ FAs (Table 8 ).

Table 8. Effect of period and supplementation with sunflower oil (SO) on nutritional quality indices of milk fat on Holstein x Gyr cows grazing on marandu grass.

\begin{tabular}{|c|c|c|c|c|c|c|c|}
\hline \multirow{3}{*}{ Variable } & \multicolumn{3}{|c|}{ Without $\mathrm{SO}^{(1)}$} & \multicolumn{3}{|c|}{ With $\mathrm{SO}^{(1)}$} & \multirow{3}{*}{$\operatorname{SEM}^{(3)}$} \\
\hline & \multicolumn{3}{|c|}{ Period $^{(2)}$} & \multicolumn{3}{|c|}{ Period $^{(2)}$} & \\
\hline & 1 & 2 & 3 & 1 & 2 & 3 & \\
\hline $\mathrm{IA}^{(4)}$ & $2.97 \mathrm{Aa}$ & $2.97 \mathrm{Aa}$ & $3.00 \mathrm{Aa}$ & $1.55 \mathrm{Ba}$ & $1.48 \mathrm{Ba}$ & $1.47 \mathrm{Ba}$ & 0.122 \\
\hline $\mathrm{IT}^{(5)}$ & $3.63 \mathrm{Aa}$ & $3.76 \mathrm{Aa}$ & $3.67 \mathrm{Aa}$ & $2.42 \mathrm{Ba}$ & $2.58 \mathrm{Ba}$ & $2.54 \mathrm{Ba}$ & 0.147 \\
\hline h/H FA ratio ${ }^{(6)}$ & $0.56 \mathrm{Ba}$ & $0.56 \mathrm{Ba}$ & $0.56 \mathrm{Ba}$ & $1.08 \mathrm{Aa}$ & $1.11 \mathrm{Aa}$ & $1.11 \mathrm{Aa}$ & 0.044 \\
\hline$\Sigma \omega-3 \operatorname{cis} \mathrm{FA}^{(7)}$ & $0.57 \mathrm{Aa}$ & $0.54 \mathrm{Ab}$ & $0.55 \mathrm{Ab}$ & $0.51 \mathrm{Ba}$ & $0.45 \mathrm{Bb}$ & $0.46 \mathrm{Bb}$ & 0.021 \\
\hline$\Sigma \omega-6$ cis $\mathrm{FA}^{(8)}$ & $1.08 \mathrm{Ba}$ & $1.21 \mathrm{Ba}$ & $1.09 \mathrm{Ba}$ & $1.36 \mathrm{Aa}$ & $1.39 \mathrm{Aa}$ & $1.42 \mathrm{Aa}$ & 0.057 \\
\hline$\omega-6 / \omega-3$ FA ratio ${ }^{(9) *}$ & $1.91 \mathrm{Bb}$ & $2.21 \mathrm{Ba}$ & $2.01 \mathrm{Bb}$ & $2.65 \mathrm{Ab}$ & $3.08 \mathrm{Aa}$ & $3.13 \mathrm{Aa}$ & 0.099 \\
\hline
\end{tabular}

*Significant interaction between Lipid supplementation*Period $(\mathrm{P}<0.05)$.

${ }^{(1)}$ Within the same treatment (inclusion or not of SO), lowercase letters indicate no significant difference $(\mathrm{P}>0.05)$ among periods; ${ }^{(2)}$ Within the same period, uppercase letters indicate no significant difference $(\mathrm{P}>0.05)$ between treatments; ${ }^{(3)} \mathrm{SEM}-\mathrm{standard}$ error of the mean; ${ }^{(4)} \mathrm{IA}$ (index of atherogenicity) $=\left[\mathrm{C} 12: 0+\left(4^{*} \mathrm{C} 14: 0\right)+\mathrm{C} 16: 0\right] /($ cis-9 C18:1 + $\Sigma$ cis $\omega-6 \mathrm{FA}+\Sigma$ cis $\omega-3 \mathrm{FA}) ;{ }^{(5)} \mathrm{IT}($ index of thrombogenicity $)=(\mathrm{C} 14: 0+\mathrm{C} 16: 0+\mathrm{C} 18: 0) /\left[\left(0.5^{*}\right.\right.$ cis $\left.-9 \mathrm{C} 18: 1\right)+\left(0.5^{*} \Sigma\right.$ cis $\left.\omega-6 \mathrm{FA}\right)+\left(3^{*} \Sigma\right.$ cis $\left.\omega-3 \mathrm{FA}\right)+(\Sigma$ cis $\omega-3 \mathrm{FA} / \Sigma$ cis $\omega-6$ FA) $] ;{ }^{(6)} \mathrm{h} / \mathrm{H}$ FA ratio (hypocholesterolemic:hypercholesterolemic FA $)=($ cis-9 C18:1 + $\Sigma$ cis $\omega-3 \mathrm{FA}) /(\mathrm{C} 12: 0+\mathrm{C} 14: 0+\mathrm{C} 16: 0)$; ${ }^{(7)} \Sigma$ cis $\omega-3=$ cis- 6 , cis-9, cis-15 C18:3 + EPA C20:5 $\omega-3+$ DPA C22:5 $\omega-3 ;{ }^{(8)} \Sigma$ cis $\omega-6=c i s-9$, cis- 12 C18:2 + cis-6, cis-9, cis-12 $\gamma-\mathrm{C} 18: 3+$ cis-11, cis-14 C20:2 + cis-8, cis-11, cis-14 C20:3 + cis-5, cis-8, cis-11, cis-14 C20:4; ${ }^{(9)} \omega-6 / \omega-3$ FA ratio (omega 6:omega 3 FA ratio $)=\Sigma$ cis $\omega-6 \mathrm{FA} / \Sigma$ cis $\omega-3 \mathrm{FA}$. 
Notably, in the treatment with SO, the oleic acid - beneficial to cardiovascular health because it reduces the plasma LDL-cholesterol concentration (FAO, 2010) - was the FA present in the highest concentration in milk fat (Table 6). The increase $(\mathrm{P}<0.0001)$ in the $\omega-6: \omega-3$ FA ratio in response to SO supplementation (Table 8 ) was a consequence of the increase $(\mathrm{P}=0.0002)$ and reduction $(\mathrm{P}=0.0055)$, respectively, of the contents of the linoleic and $\alpha$-linolenic acids in the milk fat (Table 6). However, according to the FAO (2010), no scientific consensus exists regarding the validity of this index as a metric for dietary recommendations aimed at reducing the risk of cardiovascular diseases.

From the $40^{\text {th }}$ to the $43^{\text {rd }}$ day of $\mathrm{SO}$ supplementation, temporal trends (Figure 1) revealed milk fat of better nutritional quality, since on days 42, 42 and 40, the lowest levels of lauric, myristic and palmitic (respectively, 1.05, 5.57 and

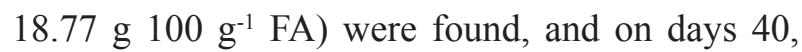
43 and 42, the highest concentrations of rumenic, vaccenic and oleic acids (respectively 1.50, 3.08

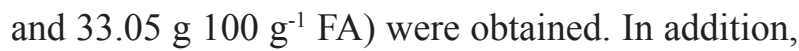
within this interval of days, the lowest IA (1.22 at 41 days) and the highest $\mathrm{h} / \mathrm{H}$ FA ratio (1.20 at 42 days) were obtained, whereas the IT remained constant ( $P>0.05)$ during the 62 days of trial. Notably, the minimum elaidic acid content $\left(0.451{\left.\mathrm{~g} 100 \mathrm{~g}^{-1} \mathrm{FA}\right)}\right.$ occurred at 36 days of SO supplementation, that is, between days 40 and 43, and its content was already declining.

\section{Conclusions}

The inclusion of sunflower oil in the diet of Holstein x Gyr cows grazing on Urochloa brizantha $\mathrm{cv}$. Marandu improved the nutritional quality of the milk fat because of the increase in oleic, rumenic and vaccenic acids, which are beneficial to human health, and because of a concomitant reduction of hypercholesterolemic saturated fatty acids, such as lauric, myristic and palmitic acids. The best results were obtained between the $40^{\text {th }}$ and $43^{\text {rd }}$ days of sunflower oil supplementation.

\section{Acknowledgements}

To Embrapa, Fapemig, $\mathrm{CNPq}$ and Capes for the financial support for this study and student scholarships; and to the technicians Ernando Ferreira Motta and Hernani Guilherme Barbosa Filho, who performed the analyses of fatty acid composition at the Laboratory of Chromatography of Embrapa Dairy Cattle.

\section{References}

ALMEIDA, M. M.; LUQUETTI, S. C. D.; SABARENSE, C. M.; CORRÊA, J. O. A.; REIS, L. G.; CONCEIÇÃO, E. P. S.; LISBOA, P. C.; MOURA, E. G.; GAMEIRO, J.; GAMA, M. A. S.; LOPES, F. C. F.; GONZÁLEZ GARCIA, R. M. Butter naturally enriched in cis-9 trans-11 CLA prevents hyperinsulinemia and increases both serum HDL cholesterol and triacylglycerol levels in rats. Lipids in Health and Disease, London, v. 13, p. 1-13, n. 200, 2014.

BUCCIONI, A.; DECANDIA, M.; MINIERI, S.; MOLLE, G.; CABIDDU, A. Lipid metabolism in the rumen: new insights on lipolysis and biohydrogenation with an emphasis on the role of endogenous plant factors. Animal Feed Science and Technology, Amsterdam, v. 174, n. 1/2, p. 1-25, 2012.

CASTAÑO, G. A.; PABÓN, M. L.; CARULlA, J. E. Concentration of trans-vaccenic and rumenic acids in the milk from grazing cows supplemented with palm oil, rice bran or whole cottonseed. Revista Brasileira de Zootecnia, Viçosa, MG, v. 43, n. 6, p. 315-326, 2014.

DHIMAN, T. R.; SATTER, L. D.; PARIZA, M. W.; GALli, M. P.; ALBRIGHT, K.; TOLOSA, M. X. Conjugated linoleic acid (CLA) content of milk from cows offered diets rich in linoleic and linolenic acid. Journal of Dairy Science, Champaign, v. 83, n. 5, p. 1016-1027, 2000.

FOOD AND AGRICULTURE ORGANIZATION OF THE UNITED NATIONS - FAO. Fats and fatty acids in human nutrition. Report of an expert consultation. Roma: FAO, 2010. 166 p.

GIRÓN, J. E. P.; RESTREPO, M. L. P.; FORNAGUERA, J. E. C. Supplementation with corn oil and palm kernel 
oil to grazing cows: ruminal fermentation, milk yield, and fatty acid profile. Revista Brasileira de Zootecnia, Viçosa, MG, v. 45, n. 11, p. 693-703, 2016.

KLIEM, K. E.; SHINGFIELD, K. J. Manipulation of milk fatty acid composition in lactating cows: opportunities and challenges. European Journal of Lipid Science and Technology, Weinheim, v. 118, n. 11, p. 1661-1683, 2016.

LIMA, L. S.; OLIVEIRA, R. L.; BAGALDO, A. R.; GARCEZ NETO, A. F.; RIBEIRO, C. V. Di M.; LANNA, D. P. D. Composition and fatty acid profile of milk from cows on pasture subjected to licuri oil supplement. Revista Brasileira de Zootecnia, Viçosa, MG, v. 40, n. 12, p. 2858-2865, 2011.

LIMA, M. L. P.; BERCHIELLI, T. T.; LEME, P. R.; NOGUEIRA, J. R.; PINHEIRO, M. G. Concentração de nitrogênio ureico plasmático (NUP) e produção de leite de vacas mestiças mantidas em gramíneas tropicais sob pastejo rotacionado. Revista Brasileira de Zootecnia, Viçosa, MG, v. 33, n. 6, p. 1616-1626, 2004.

LOPES, F. C. F. Consumo de forrageiras tropicais por vacas em lactação sob pastejo em sistemas intensivos de produção de leite. Cadernos Técnicos de Veterinária e Zootecnia, Belo Horizonte, v. 57, p. 67-117, jun. 2008.

LOPES, F. C. F.; GAMA, M. A. S.; RIBEIRO, C. G. S.; MOURTHÉ, M. H. F.; BARROS, P. A. V.; SOUZA, S. M. Produção de leite com alto teor de CLA - experiência brasileira. In: PEREIRA, L. G. R.; NOBRE, M. M.; NEVES, A. L. A.; CAMPOS, M. M.; MENDONÇA, L. C.; GOMIDE, C. A. M.; SANTOS, G. G.; SIQUEIRA, K. B. Pesquisa, desenvolvimento e inovação para sustentabilidade da bovinocultura leiteira. Juiz de Fora: EMBRAPA Gado de Leite, 2011. p. 251-296.

LOPES, F. C. F.; SILVA, B. C. M.; ALMEIDA, M. M.; GAMA, M. A. S. da. Lácteos naturalmente enriquecidos com ácidos graxos benéficos à saúde. In: MARTINS, P. C.; PICCININI, G. A.; KRUG, E. E. B.; MARTINS, C. E.; LOPES, F. C. F. Sustentabilidade ambiental, social e economica da cadeia produtiva do leite: desafios e perspectivas. Brasília: EMBRAPA, 2015. p. 237309. Disponível em: <https://ainfo.cnptia.embrapa. br/digital/bitstream/item/128155/1/Cap-13-Lv-2015Sustentabilidade-Lacteos.pdf>. Acesso em: 16 aug. 2018.

MOURTHÉ, M. H. F.; REIS, R. B.; GAMA, M. A. S.; BARROS, P. A. V.; ANTONIASSI, R.; BIZZO, H. R.; LOPES, F. C. F. Perfil de ácidos graxos do leite de vacas Holandês x Gir em pastagem de capim-marandu suplementado com quantidades crescentes de grão de soja tostado. Arquivo Brasileiro de Medicina Veterinária e Zootecnia, Belo Horizonte, v. 67, n. 4, p. 1150-1158, 2015.
NATIONAL RESEARCH COUNCIL - NRC. Nutrients requirements of dairy cattle. $7^{\text {th }}$ ed. Washington: National Academy Press, 2001. 381 p.

RIBEIRO, C. G. S.; LOPES, F. C. F.; GAMA, M. A. S.; MORENZ, M. J. F.; RODRIGUEZ, N. M. Desempenho produtivo e perfil de ácidos graxos do leite de vacas que receberam níveis crescentes de óleo de girassol em dietas à base de capim-elefante. Arquivo Brasileiro de Medicina Veterinária e Zootecnia, Belo Horizonte, v. 66, n. 5, p. 1513-1521, 2014.

SANTANA JÚNIOR, H. A.; FIGUEIREDO, M. P.; CARDOSO, E. O.; MENDES, F. B. L.; ABREU FILHO, G.; PINHEIRO, A. A.; VIANA, P. T.; ROSEIRA, J. P. S. Crude glycerin in supplement to primiparous lactating cows grazing on tropical pasture: nutritional and productive characteristics. Revista Brasileira de Zootecnia, Viçosa, MG, v. 42, n. 2, p. 117-124, 2013.

SHINGFIELD, K. J.; BERNARD, L.; LEROUX, C.; CHILLIARD, Y. Role of trans fatty acids in the nutritional regulation of mammary lipogenesis in ruminants. Animal, Cambridge, v. 4, n. 7, p. 1140-1166, 2010.

SILVA, B. C. M.; RODRIGUEZ, N. M.; MORENZ, M. J. F.; GAMA, M. A. S.; MARTINS, C. E.; PACIULLO, D. S. C.; GOMIDE, C. A. M.; ANJOS, A. J.; MADEIRO, A. S.; LOPES, F. C. F. Milk fatty acid profile of Holstein $\mathrm{x}$ Gyr cows on 'Marandu' grass pasture under different grazing strategies. Pesquisa Agropecuária Brasileira, Brasília, v. 52, n. 8, p. 652-662, 2017.

TURPEINEN, A. M.; MUTANEN, M.; ARO, A.; SALMINEN, I.; BASU, S.; PALMQUIST, D. L.; GRIINARI, J. M. Bioconversion of vaccenic acid to conjugated linoleic acid in humans. The American Journal of Clinical Nutrition, Rockville, v. 76, n. 3, p. 504-510, 2002.

VLAEMINCK, B.; FIEVEZ, V.; CABRITA, A. R. J.; FONSECA, A. J. M.; DEWHURST, R. J. Factors affecting odd- and branched-chain fatty acids in milk: a review. Animal Feed Science and Technology, Amsterdam, v. 131, n. 3/4, p. 389-417, 2006.

YANG, B.; CHEN, H.; STANTON, C.; ROSS, R. P.; ZHANG, H.; CHEN, Y. Q.; CHEN, W. Review of the roles of conjugated linoleic acid in health and disease. Journal of Functional Foods, Amsterdam, v. 15, p. 314325 , may 2015. 